\title{
Persuasion in 1 Corinthians 1:1-9
}

Author:

Andries H. Snyman ${ }^{1}$

\section{Affiliation:}

${ }^{1}$ New Testament

Department, University of the Free State, South Africa

Correspondence to:

Andries H. Snyman

e-mail:

ahs@cknet.co.za

Postal address:

Posbus 28304, Danhof,

9310, South Africa

Keywords:

persuasion; Corinthians; grounded theoretical approach; Paul's rhetorical strategy; New Testament hermeneutics

\section{Dates:}

Received: 22 Mar. 2009

Accepted: 10 June 2009

Published: 04 Sept. 2009

How to cite this article: Snyman, A.H., 2009,

'Persuasion in 1 Corinthians 1:1-9', Verbum et Ecclesia 30(2), Art. \#57, 6 pages. DOI: $10.4102 /$ ve.v30i 2.57

\section{This article is available} at: http://www.ve.org.za (c) 2009. The Authors. Licensee: OpenJournals Publishing. This work is licensed under the Creative Commons Attribution License.

\begin{abstract}
In this article, 1 Corinthians 1:1-9 is analysed from a perspective that differs from the typical approach of researchers, who tend to force ancient rhetorical categories on the letter. The analysis is done in terms of what is called a 'grounded theoretical approach'. This approach is briefly summarised, followed by a description of the rhetorical situation of the letter and a systematic analysis of these nine verses. It will be argued that these verses are an integral part of Paul's rhetorical strategy, constructed from the text itself and aimed at persuading the Corinthians to accept his authority as apostle and to follow his instructions in realising their new life in Christ. The conclusion is that a text-centred approach with its focus on the functional aspects of the text provides a better understanding of Paul's rhetorical strategy than a typical rhetorical analysis, with its focus on the formal aspects of the text.
\end{abstract}

\section{INTRODUCTION}

1 Corinthians has been the subject of much discussion among New Testament scholars, who base their analyses upon the Greco-Roman rhetorical tradition. Although they use the same tradition, they differ with regard to the dispositio of the letter and its rhetorical genre. As to the dispositio, Mitchell (1991), Schrage (1991) and Witherington (1995) agree that the thanksgiving in 1:4-9 forms a rhetorical exordium, which leads to the propositio in 1:10, followed by the narratio in 1:11-17. They differ, however, with regard to the demarcation of the probatio. Mitchell (1991:xi) ends her probatio with the conclusion of the deliberative argument in 15:58 while Witherington extends it to 16:12. There is also no consensus as to the closing of the letter.

With regard to the rhetorical genre of 1 Corinthians, scholars generally accept that it is an example of deliberative rhetoric (Mitchell 1991; Schüssler-Fiorenza 1987; Witherington 1995). The classicist Kennedy, however, is of the opinion that the genre of 1 Corinthians is best understood as 'largely deliberative, although it contains some judicial passages' (1984:87). Wuellner (1979:177-188) again, who relies on Perelman and Olbrecht-Tyteca's redefinition of the epideictic genre, argues that 1 Corinthians is epideictic. The variety of these interpretations casts serious doubt on the theoretical justification for applying categories of classical rhetoric to Paul's letters.

An interesting feature of rhetorical analyses of 1 Corinthians is the tendency to analyse individual chapters in the letter, arguing that each of them displays the traditional dispositio and represents a specific rhetorical genre. Examples include the analyses of Smit (1993:211-230) of 1 Corinthians 12-14 and those of Bünker (1984:59-72), Shaw (1995) and Watson (1993:231-249) of 1 Corinthians 15. Bünker, for example, argues that 1 Corinthians 15 is judicial while Watson and Shaw regard it as a piece of deliberative rhetoric. It is probably assumed that these chapters could be analysed as speeches in 1 Corinthians while the letter as a whole could also be analysed in terms of the same rhetorical categories. Porter (1997:554) is correct in asserting that the value of such analyses is difficult to determine, in so far as they reveal the profitable use of ancient rhetorical categories in the interpretation of these chapters.

As a result of these and other concerns (such as the mixing of epistolary and rhetorical categories), New Testament scholars started analysing Paul's letters without using ancient rhetorical categories. They began to apply modern rhetorical theories, or they analysed the arguments in a letter in terms of a text-centred approach, whereby the letter itself serves as starting-point for analysis. Examples of the latter are the analyses of Anderson (1999) of Galatians 1-5:12, Romans 1-11 and 1 Corinthians, as well as the works of Kern (1998) and Tolmie (2005) on Galatians.

The purpose of this article is to study persuasion in 1 Corinthians 1:1-9 in terms of Tolmie's proposal for rhetorical analysis. His proposal will be summarised, followed by an analysis of these nine verses. I hope to prove that a text-centred approach, aimed at reconstructing Paul's rhetorical strategy from the text itself, provides a better understanding of his rhetoric than using ancient rhetorical categories from outside.

\section{RHETORICAL ANALYSIS FROM A TEXT-CENTRED PERSPECTIVE}

A text-centred approach is exactly what it says: It involves an analysis of the rhetoric of the text that focuses primarily upon identifying and describing the rhetorical strategies from the text itself instead of making the text fit into a preselected rhetorical model. Scholars opting for this approach regard it better to let the text 'speak for itself' or to 'trust in the text and in its internal logic' (Meynet 1998:177). Tolmie's (2005) proposal represents one way of describing the persuasive force of Paul's letters from such a perspective. It has proved fruitful in analysing other letters of Paul and will be used to describe persuasion in the first nine verses of 1 Corinthians.

Since it is impossible to analyse a text in a totally objective way, Tolmie (2005:27-30) gives an explanation of the approach that he used in analysing the letter to the Galatians. His purpose is not to prescribe a fixed methodology, but to provide a general guideline for analysis. After constructing the rhetorical situation or context, that is, the broad outline of what Paul wants to achieve in the letter 
as a whole, he formulates his 'minimal theoretical framework', consisting of the following aspects:

- The identification of the dominant rhetorical strategy in a particular section by answering two questions: 'How can one describe Paul's primary rhetorical objective in this section?', and 'How does he attempt to achieve this objective?'

- The analysis of the section by focusing on the types of argument Paul uses and why they are effective or by describing the manner in which he argues to persuade his audience. Exegetical issues are discussed, especially when there is not agreement on the meaning of a specific phrase or expression of rhetorical significance.

- The identification of the rhetorical techniques Paul uses to enhance the impact of his communication.

- A description of the way in which the argument in the letter as a whole has been organised. Of course, this aspect can only be addressed once the analysis of the whole letter has been completed. (See Tolmie 2005:122-123 for his description of the argument in Galatians.).

\section{RHETORICAL CONTEXT}

The rhetorical situation or context in which Paul wrote this letter might be conceived as follows:

'Those of Chloe' in 1:11 supplied him with oral information about the situation in Corinth. Most probably they also presented him with the letter referred to in 7:1 (SchüsslerFiorenza 1987:395). From these two sources Paul learnt, first of all, about the divisions and partnership in Corinth, which had implications for his apostolic authority. It is unlikely that a group of anti-Pauline agitators were causing these problems, as Marshall (1987:23-27) argues. The difficulties were essentially internal and resulted in divisions among the Corinthians themselves (Pogoloff 1992:237; Schüssler-Fiorenza 1987:397-398 Witherington 1995:74). Fee (1988:6) also agrees that the church was experiencing internal strife but argues convincingly that the greater problem was the division between Paul as the founder of the church and some influential teachers who were leading the Corinthians in an anti-Pauline direction. For Paul this greater conflict presents a crisis over his apostolic authority as well as the truth of his message. Exegetes agree that the key issue between Paul and his audience was what it meant to be pneumatikos. The Corinthians made glossolalia the basic criterion of spirituality while their interest in sophia and gnosis gave them special wisdom and superior knowledge. All of this is opposed to both Paul and his gospel and results in boasting and false confidence, which needs to be addressed.

Secondly, 1 Corinthians was written in response to certain practical issues raised in the letter Paul received from them. The major issues that needed to be settled were marriage and sexuality (5-7), meat sacrificed to idols (8:1-11:1), worship (11:2$14: 40)$, resurrection $(15: 12-37)$ and the collection for the saints (16:1-4). In response to these issues as well as to the oral reports of Chloe's people, Paul addresses various - mainly behavioural - concerns in the letter.

In her much-quoted article Rhetorical situation and historical reconstruction in 1 Corinthians, Schüssler-Fiorenza (1987:397-398) describes the rhetorical situation as follows: The Corinthians had debates as to how their new life in Christ could be realised in the midst of a society rooted in divisions between Greek and Jew, slave and free, man and woman, etc. These debates dealt with issues such as 'no longer male and female' and marriage relationships. In the light of competing interpretations and practices they decided to write to different missionaries (including Paul) for their advice, since some of the interpretations most likely originated in different theological views held by these missionaries. This consultation process did not mean that they would accept such advice without judgement in terms of their own pneumatic self-understanding. According to some of the Corinthians, Paul was not well qualified in terms of pneumatic competence. The apostle must somehow have learnt this and in order to convince them to accept his interpretation, he had to argue why they should follow his instructions and not those of the other missionaries. In the process of persuasion, Paul presented himself as the sole founder and father of the church in Corinth who must be obeyed and not as one apostle among others.

Whether one accepts this specific reconstruction or not, the broad picture remains the same: The letter is dominated by Paul's attempt to persuade the Corinthians to accept his authority as apostle (including the truth of his message) and to follow his instructions in realising their new life in Christ. He is not addressing a single subject but a wide variety of issues, using a variety of arguments and persuasive techniques. To examine these in the first nine verses of the letter is the aim of this paper.

\section{ANALYSIS OF 1 CORINTHIANS 1:1-9}

\section{Introduction}

Two issues need attention before analysing Paul's persuasive strategy in these nine verses:

- Scholars who follow Betz in his approach to rhetorical analysis define $1: 1-3$ as the epistolary prescript and 1:4-9 as the exordium of the letter (Mitchell 1991:192197; Witherington 1995:78-94). The primary aim of the exordium was to prepare the audience psychologically for the speaker and his case. As Lausberg (1960:180) puts it, 'Ziel des exordiums ist es, die Sympathie des Richters (oder im weiteren Sinn: des Publikums) für den (parteimässig vertretenen) Redegegenstand zu gewinnen.

- In line with this definition, Watson (1988:62) highlights three functions of the exordium: '...to obtain audience attention, receptivity and goodwill'. The major drawback in describing 1 Corinthians $1: 4-9$ as exordium is that it leads to a degradation of the argumentative value of this part of the letter. The exordium (and narratio) cannot merely be regarded as 'preparatory' for the 'real' arguments in the probatio, as Tolmie (2005:46-47) points out in his analysis of Galatians. He distinguishes between the theological content of Paul's arguments and their persuasive value. Even if the arguments at the beginning of a letter may appear less 'theological' in nature, it does not imply that they should be viewed as inferior or less persuasive than the ones used later on in the letter. On the contrary: It might just be that Paul preferred to use his best arguments first!

- In this analysis 1 Corinthians 1:1-9 has been demarcated by rhetorical considerations from the text itself. It consists of three sections. The first three verses are separated from verses $4-7$ a by the verb eu c a r is t w 'in verse 4 , indicating a shift in Paul's rhetorical strategy. In 1:7b-9 he moves from thanksgiving to an eschatological perspective, which has an important function in his persuasive strategy. In 1:10 there is another shift when he starts appealing (pa ra kal w ) to his audience in the light of the divisions among them. Thus, the three sections in 1:1-9 are verses $1-3,4-7 \mathrm{a}$ and $7 \mathrm{~b}-9$.

- How should one describe the rhetorical strategy in each of these sections? In 1:1-3 Paul is emphasising the divine origin of his apostleship and the Corinthians' calling as 'church of God, sanctified in Christ Jesus'. The dominant strategy in this section could thus be described as 'adapting the salutation to emphasise his and their divine calling'. In the second section (1:4-7a) he thanks God for the Corinthians themselves and for the gifts they have received. The strategy in the third section, dealing with eschatology, could be described as 'assuring the Corinthians of their future glory, thereby persuading them to use their gifts correctly' (1:7b-9).

The rest of the article will be devoted to a verse-by-verse analysis of the way in which Paul tries to persuade his audience to his point of view. 


\section{Corinthians 1:1-3: Adapting the salutation to emphasise his and their divine calling}

In the opening section of his letters Paul usually employs the three traditional elements of sender, receiver and greetings but describes the sender(s) and receiver(s) in more detail (Schnider \& Stenger 1987:4-24). The greeting of a traditional letter (c a i r ein) is also changed to 'grace and peace to you' and Christianised (White 1984:1730-1756). Although Paul follows the traditional pattern, he adapts it to the particular occasion of the letter in order to strengthen his overall rhetorical strategy (Tolmie 2005:31).

\section{The designation of the senders}

The two senders are described as $\mathrm{P}$ a u $\mid 0 \sim \mathrm{kl} h \mathrm{ht} 0, \boldsymbol{r}$ a posit ol $0 \sim$ Cristou 'Ihsou 'dia; gelhmato qeou 'and $S$ ws qe wh $~ 0$ l a d el $\mathrm{f} 0 \forall$. Paul stresses two aspects in describing himself. The first is that he is 'called to be an apostle of Christ Jesus'. The use of these words in the salutation implies that his apostleship was such an important issue that he used the very first opportunity in the letter to address it - as is the case in the letter to the Galatians. Given the tensions between Paul and the Corinthians, who are questioning his apostleship, Paul asserts that he is an apostle commissioned by the Lord Himself. Secondly, he emphasises the origin of his apostleship with the addition 'by the will of God'. There has been some discussion as to whether the addition qualifies kl hto $\forall$ or a post ol o Cristou ' hhsou, or both (see Barrett 1979:30-31). Conzelmann (1975:20) and Fee (1988:29) agree that it includes both ideas. This interpretation is supported by the placement of dia; qel h mat $0 \sim$ qeou 'at the end of the description in an emphatic position. The addition bases his apostleship in God's eternal plan.

An examination of 1:1 reveals that the primary aim of the addition is to emphasise in a forceful way that Paul's apostleship is completely dependent on God. The type of argument used could be defined as an argument based on divine authorisation. It is assumed that in order to be an apostle of Jesus Christ, one should have been called by God. The importance of this argument - from Paul's perspective - is clear from the fact that he uses it at the very beginning of the letter.

Paul is joined by a coworker described as 'Sosthenes, the/our brother'. Conzelmann (1975:20) and Thiselton (2000:69-70) are of the opinion that it is not necessary to speculate on his relation to the Sosthenes of Acts 18:17, since the name was widely used. Barrett (1979:31), on the other hand, thinks that he is probably the Sosthenes of Acts 18:17 and well-known to the Corinthians. The point is that there should have been a reason for mentioning his name as a cosender. This fact as well as the designation 'my/ our brother' suggests that Barrett is most probably correct.

Important for our purpose is the fact that the name of Sosthenes is added after Paul's description of himself as someone 'called to be an apostle of Christ Jesus by the will of God'. This word order differs, for example, from Philippians 1:1 ( $\mathrm{P}$ a u l o ka i ; Timogeo douloi Cristou ' (hsou) and almost certainly excludes Sosthenes from being an apostle as well. Its primary function is to emphasise Paul's apostolic authority as over against his coworker. The Corinthians would most certainly have realised this as well as the fact that the 'our' is inclusive: it includes the whole Christian community in Corinth.

\section{The description of the receivers}

As is the case with the senders, the extensive description of the receivers is directed towards the situation in Corinth. The letter is addressed

to the church of God in Corinth ( $\mathrm{t}$ /'e lik k h s i a / t ou 'qeou 't h / ou $\$ \mathrm{~h} / \mathrm{e}$ n K or ingw Y, to those sanctified in Christ Jesus and called to be holy (hig menoi e n C rist w l'jhsou, kl ht oi i a gi $\mathbf{i}$ i ), together with all those everywhere who call on the name of our Lord Jesus Christ - their Lord and ours (t $0 ; 0$ homa to u '

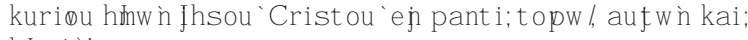
h mmw ǹ)!.

(1 Cor 1:2).

The following issues are rhetorically significant in this description. Firstly, the qualification of the church as 'the church of God'. As Thiselton (2000:73-74) points out, the function of this qualification is to address at the outset one of the problems among the Corinthians: The church does not belong to the wealthy or to people who manifest certain spiritual gifts. The church belongs to God, to whom everyone is accountable.

Secondly, they are described as 'sanctified in Christ Jesus and called to be holy'. The verb a gia z $\mathrm{z}$ means 'to cause someone to have the quality of holiness - to make holy' (Louw \& Nida 1988:745) and the preposition en with Cristw / jhsou' is instrumental, referring to the work of salvation which God accomplishes 'in Christ' (Conzelmann 1975:21). Similarly, God or Christ is the subject of their calling ( $k \mid h$ t oi $i)$ to be holy. The adjective a i $10 \sim$ means 'possessing certain essentially divine qualities in contrast to what is human' (Louw \& Nida 1988:745). The type of argument used here is an argument based on divine involvement. This type of argument is highly effective and is frequently used in 1:1-9 as well as in Paul's other letters. Here it is used to emphasise the human-divine opposition, which plays such an important role in the rest of the letter. As such it prepares the audience for what is coming and enables them to understand at the outset their responsibility as people of God. They must bear the character of the One who has called them to be his people.

The third issue pertains to the phrase 'together with all those everywhere who call on the name of our Lord Jesus Christ their Lord and ours'. The syntax poses some problems for interpreters. Is it to be connected to the immediately preceding 'called to be holy' or to 'the church of God in Corinth' or even to the senders Paul and Sosthenes in verse 1? Fee discusses the possibilities and concludes that the point is quite clear:

The pneumatikoi in Corinth seem to have struck an independent course, both from Paul and therefore also from the rest of the churches... So Paul starts by giving them a gentle nudge to remind them that their own calling to be God's people belongs to a much larger picture.

(Fee 1988:33)

Fee's conclusion is supported by Paul's argumentation in the remainder of the letter (4:17; 11:16; and 14:36).

As such the phrase has two important functions. Firstly, it associates the Corinthians with all the other churches, thereby strengthening their relationship and focusing on their 'togetherness'. The Corinthians have a share with all the saints who 'call on the name of our Lord Jesus Christ'. Secondly, it strengthens Paul's apostolic authority in the sense that what he is saying to them, he is saying to all the churches. There is a large group of people standing behind him and for whom he - as apostle - is responsible. He is the apostle of the universal church, as the prepositional phrase e i p a nt $\mathrm{i}$; $\mathrm{t}$ op w /indicates.

According to Schüssler-Fiorenza (1987:398), Paul claims the authority of Christ and that of other churches whenever his argument breaks down. I am of the opposite opinion. As in his other letters (especially Galatians but also Romans and Philippians) he is using this authority as one of his strongest arguments in order to persuade his audience to his point of view. The audience must first of all be persuaded of who he is before they can pay attention to what he has to say. This is why he uses this argumentation at the very beginning of the letter.

The salutation is concluded by the traditional 'grace and peace to you from God our Father and the Lord Jesus Christ', also used in Paul's other letters. The inclusive 'our' is used to bind Paul to his audience and to create a common understanding between them. 
In addition to 'inclusive language', the following rhetorical techniques have been identified in 1:1-3:

- Repetition of 'God' and 'Christ Jesus/Jesus Christ' in all three verses, emphasising the divine involvement that characterises the section.

- Paranomasia with høiasmeroi / a gi øi and pas̀in / pant ivin 1:2 creates links between key items, thereby effectively highlighting them.

- Furthermore, the description of the receivers as h gias me roi / a gi $\propto$ i emphasises their privileged status, thus bestowing honour upon them. Genade (2007:184) calls this technique honorific referencing or classification, here used to build a relationship between Paul and his audience.

- he placement of aufwì kai; h mwin at the end of $1: 2$ emphasises the 'togetherness' of all the saints 'who call on the name of our Lord Jesus Christ'.

To conclude: Paul's rhetorical strategy in 1:1-3 can be described as 'adapting the salutation to emphasise his and their divine calling'. He begins by describing himself as one 'called to be an apostle of Christ Jesus', thereby using the very first opportunity in the letter to address the issue of his apostleship. His apostleship is further strengthened by an argument based on divine authorisation, while the word order in 1:1 also serves to highlight his apostolic authority.

The description of the receivers is also aimed at addressing the situation in Corinth. Of the various ways in which Paul adapts the receiver element, two are of special significance. Firstly, the argument based on divine involvement, used to emphasise the human-divine opposition and to enable the Corinthians to understand their responsibility as God's holy people. Secondly, the phrase 'together with all those everywhere who call on the name of our Lord Jesus Christ, their Lord and ours', which serves to associate the Corinthians with all other churches, thereby highlighting Paul's apostleship of the universal church.

Rhetorical techniques enhancing Paul's communication in 1:1-3 include repetition of names, paranomasia, honorific referencing and the placement of a uf $w \hat{n} \mathrm{ka} i ; \mathrm{h} m w \hat{n}$ at the end of $1: 2$.

\section{Corinthians 1:4-7a: Thanking God for the Corinthians and their gifts}

This section is demarcated by a shift in Paul's persuasive strategy. Verses $4-7$ a deal with the grace and gifts given to the Corinthians while verses $7 b-9$ refer to the final consummation at the coming of Christ. It is a shift from the past to the present/ future, from thanksgiving to a strong affirmation, from the graces they have received to what God will do for them 'on the day of our Lord Jesus Christ'. Thus, although 1:4-8 is a single sentence in the original, the second part of verse 7 paves the way for the affirmation in verses $8-9$ and will be discussed in the next section.

Verses 4-8 read as follows:

I thank my God always for you on the ground of his grace (e p i ; $\mathrm{h}$ \% ca rit i t ou 'qeou ), given to you in Christ Jesus (t h / d d qeis/ / umi ǹ en Cristw \% los ou ), in that (o $\mathrm{k}$ i) in him you have been enriched (e $\dot{p} \mid$ out is qht e) in every respect (e n pant $\mathrm{i} y$ - in all your speaking and in all your knowledge (e $\mathrm{n} p \mathrm{nt} i ; \mathrm{log} / \mathrm{ka}$ $\mathrm{p}$ a s $\mathrm{h} / \mathrm{gnws}$ ei) - just as (ka qw $\forall)$ our testimony about Christ was confirmed (e beba i w gh) in you so that you fall short in no gift (e n mh d eni ; c a r is ma t i), while you wait for the revealing of our Lord Jesus Christ.

(1 Cor 4-8)

Considerable research has been done on the Pauline thanksgivings. Thiselton (2000:85-87) discusses four stages of research, ending with O'Brien's work Introductory thanksgivings in the letters of Paul (1977). A shared characteristic of Paul's thanksgivings and the Greek epistolary literature was to express thanks for some aspects that would then be developed more fully in the body of the letter (O'Brien 1977:107-137). This is also the case in $1: 4-8$, as will become clear in the analysis below.

The basis of Paul's thanksgiving is God's 'grace given you in Christ Jesus'. The term cavi is associated with carismmat a and refers to concrete expressions of God's gracious activity in the Corinthians (Fee 1988:37). Such a concrete understanding of grace is supported by verses $5-7$, in which manifestations of certain gifts are referred to - manifestations that the Corinthians prize very highly and boast about. As indicated above, Paul does not develop the issue of the c a r i s mat a at any length here but merely refers to it. The reference, however, is important from a rhetorical perspective. Paul stresses the fact that the grace (and gifts) they received were given to them by God. As such it represents another argument based on divine involvement. Precisely because these gifts were given by God, the Corinthians had no reason for boasting. Thus, Paul is arguing from the beginning of his letter, trying to persuade his audience to share his point of view by stopping their boasting over things they have received and starting to focus on God, who gave them these gifts.

In verse 5 Paul continues with the same argument by explaining that the Corinthians have been enriched (e $p \mid$ out is ght e) in every respect. Scholars differ as to the meaning of $0 \mathrm{H} i$ at the beginning of the verse. Does it mean 'because' or 'that' and should it be linked to eugrarist w' or to th '/dogeis/h/umi ǹ en Cristw / Ihsou? Barrett (1979:36) favours the meaning 'because' on the basis of parallels in Greek letter forms. Conzelmann (1975:25) also prefers 'because' and links it to eu ç a r is t w ' ('I thank God...because'). Grosheide (1957:39) and Thiselton (2000:90), on the other hand, are of the opinion that $0 \mathrm{k} \mathrm{i}$ is explicative, indicating that what follows modifies verse 4. As such it could be translated 'in that', which renders the translation, 'I thank my God...on the ground of his grace given to you in Christ Jesus, in that...' (or 'I mean...'). The structure of the sentence in the original justifies such an interpretation.

Thus, verses 5-7 spell out in more detail the meaning of the grace given to the Corinthians in Christ Jesus: They were enriched in Christ in every respect. The gifts are to be understood as manifestations of God's grace. This argument of divine involvement once again serves to focus their attention on God and away from the gifts per se - the gifts as source of their boasting.

The two gifts mentioned explicitly in 1:5, namely $\log 0 \sim$ and gnws $\mathrm{i} \sim$, should be interpreted in this context. Whatever their specific meaning, they are given by God for the edification of the church and are not something human about which the Corinthians could boast. This issue will be developed at length later on in the letter (chapters 12-14). For now Paul merely mentions it and expresses his thanks to God for the gifts, thereby trying to persuade his audience to do the same by focusing on God.

As is the case with $0 \sharp i$ at the beginning of 1:5, the conjunction kagw $\forall$ in 1:6 creates problems for interpreters. Conzelmann (1975:27) proposes the translation 'for indeed', while O'Brien (1977:120) and Thiselton (2000:94) see it as introducing a causal clause, explaining the reason for their richness of spiritual gifts. Grosheide (1957:40) and Fee (1988:40), again, argue for the ordinary comparative sense of kaqw $\forall$ ('just as/even as'). Fee finds support for his interpretation in 1 Thessalonians 1:5 where Paul asserts that his gospel came with power, the Holy Spirit and deep conviction and then adds the reminder kaqw, oi date oi joi i e genh ghmen (e ñ) umi ǹ di juma $\sim$ ('just as you yourselves know how we lived among you for your sake'). Here in 1 Corinthians 1:6 it suggests that the gifts are the evidence that Paul's testimony about Christ was confirmed in the Corinthians. 
Fee's well-motivated interpretation is to be preferred to that of $\mathrm{O}^{\prime}$ Brien, Thiselton and others. If correct, it means that God confirmed Paul's testimony to Christ among the Corinthians by giving them the spiritual gifts in 1:5. The true proclamation of Christ was confirmed in their own experience by way of the gifts they received.

Two issues are of rhetorical significance in 1:6. The first is the use of an argument based on own experience. This type of argument is very powerful and persuasive, since people are not prone to doubt their own experience. They actually have no other option but to agree. This is exactly what Paul achieves in 1:6: He bases his argument on earlier experiences of the Corinthians, which they now cannot deny. These experiences include above all else their experience of the gifts they received, which proves the truth of his message.

Secondly, the one who confirms (ebebaiwgh) Paul's witness to Christ among the Corinthians was God Himself. This argument of divine involvement also serves to guarantee the truth of Paul's gospel: They have been enriched by the gifts God Himself gave them. Thus, by way of two strong arguments Paul is trying to persuade his audience as to the truth of his testimony to Christ.

With the result clause w\$t e u ma $\sim$ mh; u t ter ei s̀ qa i e n mhdeni; caris mat i in 1:7a Paul brings his thanksgiving to a close. The clause merely repeats negatively what has been stated positively in verse 5 (Conzelmann 1975:27). The repetition emphasises that the gifts of grace are indispensable as part of the Christian life; without these gifts the Corinthians would fail to fulfil their calling.

In addition to the repetition just mentioned, the prepositional clause en Cristw '/fhsou '(1:4) is repeated with en a uf w'/in 1:5 to emphasise Christ's instrumental role, while paranomasia with pa vt ot e (1:4), e j pant i v(twice) and pash /in 1:5 is used as supportive rhetorical technique to stress the totality or completeness of what is said.

To conclude: The rhetorical strategy in 1:4-7a could be described as 'thanking God for the Corinthians and their gifts'. Arguments based on divine involvement are used to good effect (in 1:4, 1:5 and 1:6) while the argument of the Corinthians' own experience in 1:6 leaves the audience with no other option but to accept the truth of Paul's testimony to Christ.

The techniques of repetition and paranomasia highlight keynotes in the argumentation.

\section{Corinthians 1:7b-9: Assuring the Corinthians of their future glory, thereby persuading them to use their gifts correctly}

Paul shifts his persuasive strategy from thanksgiving to an assurance of future glory when he writes,

...while you are waiting for (a pekdec ome nou ) the revelation of our Lord Jesus Christ; He (God) will also confirm you (o f ka i beba i ws ei u ma $\sim$ ) to the end, so that you will be blameless on the day of our Lord Jesus Christ. God is faithful (p is t 0,0 l J ge o i), by whom you have been called (e $\mathrm{k} / \mathrm{h}$ ght e) into fellowship with His son Jesus Christ, our Lord.

(1 Cor $1: 7-8)$

Two issues are rhetorically significant in this section. The first relates to the phrase 'while you are waiting for the revelation of our Lord Jesus Christ'. What is the function of this eschatological note at the end of verse 7? Groenewald (1967:22) is of the opinion that the Corinthians had a sound expectation of Christ's return - unlike many other churches - as a result of which they were using their gifts correctly and with diligence. Thus, the function of the note is to encourage them to continue in the same vein. The majority of commentators, however, argue that the Corinthians had an 'overrealised eschatology' (based on the spiritual gifts they had received, especially the gift of tongues), which repressed their eager expectation of Christ's coming (Barrett 1979:39; Fee 1988:43; Grosheide 1957:43). Therefore, Paul finds it necessary to remind them that the present is still incomplete and that all Christians are still awaiting the revelation of the Lord.

Which interpretation is to be preferred? Probably the second one, mainly due to the rhetorical context of the letter. The Corinthians' experience of the gifts allows them to be pompous as if the final word has already been spoken. Therefore, Paul's aim is to deflate this pomposity, without awakening terror (Barrett 1979:39). The linguistic context of the phrase also supports this interpretation: The Corinthians do not lack any spiritual gift as/ while they wait for (praes part a p ekdec o me vou $\sim$ ) the revelation of the Lord. By adding this note Paul is trying to persuade the Corinthians by reminding them that the final revelation of Christ is yet to come and that the gifts have to be used in the light of this eschatological event.

The second issue of rhetorical significance is the antecedent of the relative of at the beginning of verse 8. Is it God or Jesus Christ? Grammatically it could only be Jesus Christ at the end of verse 7. This interpretation is preferred by Barrett (1979:39) and Godet (1957:58) while Conzelmann (1975:28), Groenewald (1967:22) and Grosheide (1957:43) are in favour of the first option, namely God. Schrage (1991:121) and Thiselton (2000:101) leave the matter open and translates the relative with ' $\mathrm{He}^{\prime}$.

To my mind the antecedent of $0 \mathrm{f}$ is God, for two reasons:

1. The type of argument that dominates 1 Corinthians 1:1-9 is an argument based on God's involvement. Here in 1:8 Paul is using it once again to good effect. God is also the subject of epebaiwgh in 1:6, where the verb was used for the first time, while the kai vin of kai; bebaiwsei (left untranslated by, inter alia, Conzelmann 1975:28 and the NIV) supports this interpretation.

2. To begin and end verse 8 with Jesus Christ renders the translation 'Jesus Christ will also confirm you to the end, so that you will be blameless on the day of our Lord Jesus Christ'. Such a statement is awkward and to a certain extent senseless. Thus, although Jesus Christ is grammatically the only antecedent of of , it makes better sense to translate the passage as 'God will confirm you...on the day of our Lord Jesus Christ'.

In line with his persuasive strategy up to now, Paul is once again using an argument of divine involvement in 1:8 to redirect the Corinthians' attention from themselves to God, who assures their future glory. The apostle is confident that God will confirm them to the end, as is clear from the future indicative beba i ws ei, which expresses a certainty (as Conzelmann 1975:28 argues correctly, with reference to e p it el es ei in Phil 1:6), not a wish.

The argument of God's involvement is finally used in the summary statement of verse 9: 'God is faithful, by whom you were called (e $\mathrm{kl} h \mathrm{~h}$ hte) into the fellowship of His Son Jesus Christ, our Lord.' God is the only author and guarantee of the Corinthians' existence, both in terms of their calling and their future glory.

Rhetorical techniques used to enhance Paul's communication in this section are the following:

- The clause tou 'kuriau h mw ǹ Ihs ou 'C rist ou 'is repeated at the end of verses 7, 8 and 9 in an emphatic position. It serves to highlight that everything God is doing for the Corinthians is done in/through Jesus Christ.

- The inclusive 'we' in all the clauses quoted above serves to bind Paul to his audience, thereby achieving a common understanding between them. 
- $\quad$ is t $0 \forall$ is placed first in 1:9 to emphasise this characteristic of God.

- The clause pistor of qeo $\forall$ is not linked to the previous sentence (asyndeton), indicating that Paul is shifting to a new (summative) statement in verse 9.

To conclude: Paul's persuasive strategy in 1:7b-9 could be described as 'assuring the Corinthians of their future glory, thereby persuading them to use their gifts correctly'. The phrase 'while you wait for the revealing of our Lord Jesus Christ' (1:7b) serves to deflate their pomposity and to persuade them to view their gifts from an eschatological perspective. The assurance itself is based on an argument of divine involvement (1:8) while God is also the sole author of their calling and future glory (1:9)

Rhetorical techniques in this section include repetition, inclusive language, placement of words and asyndeton.

\section{CONCLUSION}

The aim of this article was to prove that Paul's persuasive strategy in 1 Corinthians 1:1-9 can be reconstructed from the text itself, without using rhetorical categories from outside. I hope to have proved that these introductory nine verses are not only preparatory for the 'real' arguments in the so-called probatio but are already an integral part of Paul's argumentation in the letter.

1 Corinthians 1:1-9 is demarcated by rhetorical considerations and divided into three sections: $1: 1-3 ; 1: 4-7 \mathrm{a}$ and $1: 7 \mathrm{~b}-9$. In analysing them, the focus was on the way Paul argues, on the types of arguments he uses and on the rhetorical techniques that could enhance the impact of his communication. Examples of arguments based on divine authorisation, on divine involvement (which dominate all three sections) and one based on own experience have been identified, while supportive techniques such as repetition, paranomasia, inclusive language, the placement of words, honorific referencing and asyndeton all contribute to the impact of his communication and serve to persuade Paul's audience to his point of view.

\section{REFERENCES}

Anderson, R.D., 1999, 'Ancient rhetorical theory and Paul', Catholic Biblical Quarterly 18.

Barrett, C.K., 1979, A commentary on the first epistle to the Corinthians, 2nd edn., Black, London.

Bünker, M., 1984, 'Briefformular und rhetorische Disposition im 1 Korintherbrief', Gestalt Theory 28.

Conzelmann, H., 1975, 1 Corinthians: A commentary on the first epistle to the Corinthians, Fortress Press, Philadelphia.

Fee, G.D., 1988, The first epistle to the Corinthians, Eerdmans, Grand Rapids.

Genade, A.A., 2007, 'A text-centred rhetorical analysis of Paul's letter to Titus', PhD dissertation, University of the Free State.

Godet, F., 1957, Commentary on the first epistle to the Corinthians, Eerdmans, Grand Rapids.

Groenewald, E.P., 1967, Die eerste brief aan die Korinthiërs, NG Kerk Uitgewers, Cape Town.

Grosheide, F.W., 1957, De eerste brief aan de Kerk te Korinthe, N.V. Uitgeversmaatschappij J.H. Kok, Kampen.

Kennedy, G.A., 1984, New Testament interpretation through rhetorical criticism, University of North Carolina Press, Chapel Hill.

Kern, P.H., 1998, Rhetoric and Galatians: Assessing an approach to Paul's epistle, SNTS.MS101, Cambridge University Press, Cambridge.

Lausberg, H., 1960, Handbuch der literarischen Rhetorik, Max Hueber, München.

Louw, J.P. \& Nida, E.A., 1988, Greek-English lexicon of the New Testament based on semantic domains, UBS, New York.
Marshall, P., 1987, 'Enmity in Corinth', Wissenschaftliche Untersuchungen zum Neuen Testament 2.23, J.C.B. Mohr, Tübingen.

Meynet, R., 1998, Rhetorical analysis: An introduction to biblical rhetoric, Sheffield Academic Press, Sheffield.

Mitchell, M., 1991, Paul and the rhetoric of reconciliation: An exegetical investigation of the language and composition of 1 Corinthians, Mohr-Siebeck, Tübingen.

O'Brien, P.T., 1974, 'Thanksgiving and the Gospel in Paul', New Testament Studies 21(1), 144-155.

Pogoloff, S.M., 1992, Logos and sophia: 'The rhetorical situation of 1 Corinthians, Scholars Press, Atlanta.

Porter, S.E., 1997, 'Paul of Tarsus and his letters', in S.E. Porter (ed.), Handbook of classical rhetoric in the Hellenistic period 330 $B C-A D$ 400, pp. 532-585, Brill, Leiden.

Schnider, F. \& Stenger, W., 1987, Studien zum neutestamentlichen Briefformular, New Testament Studies 12, EJ Brill, Leiden.

Schrage, W., 1991, Der erste Brief an die Korinther, 1 Teilband, EKKNT 7/1, Benzinger, Zürich.

Schüssler-Fiorenza, E., 1987, 'Rhetorical situation and historical reconstruction in 1 Corinthians', New Testament Studies 33, 386-403.

Shaw, I., 1995, Paul's rhetoric in 1 Corinthians 15: An analysis utilizing the theories of classical rhetoric, Mellen, Lewiston.

Smit, J., 1993, 'Argument and genre of 1 Corinthians 12-14', in S.E. Porter \& T.H. Olbricht (eds.), Rhetoric and the New Testament, JSNT Supplement Series 90, pp. 211-230, Sheffield Academic Press, Sheffield.

Thiselton, A.C., 2000, 'The first epistle to the Corinthians: A commentary on the Greek text', Nederduits Gereformeerde Teologiese Tydskrif, WB Eerdmans Publishing Company, Grand Rapids.

Tolmie, D.F., 2005, 'Persuading the Galatians: A text-centred rhetorical analysis of a Pauline letter', Wissenschaftliche Untersuchungen zum Neuen Testament II 90.

Watson, D.F., 1988, 'A rhetorical analysis of Philippians and its implications for the unity question', Novum Testamentum 30 , 57-88.

Watson, D.F., 1993, 'Paul's rhetorical strategy in 1 Corinthians $15^{\prime}$, in S.E. Porter \& T.H. Olbricht (eds.), Rhetoric and the New Testament, Journal for the Study of the New Testament Supplement Series 90, pp. 231-249, Sheffield Academic Press, Sheffield.

White, J.L., 1984, 'New Testament epistolary literature in the framework of ancient epistolography', Aufsteig und Nedergang der römischen Welt 25(2), 1730-1756.

Witherington, B., 1995, Conflict and community in Corinth: A socio-rhetorical commentary on 1 and 2 Corinthians, Eerdmans, Grand Rapids.

Wuellner, W., 1979, 'Greek rhetoric and Pauline argumentation in early Christian literature and the classical intellectual tradition, in Honorem Robert Grant', Theologie Historique 53, 177-188. 